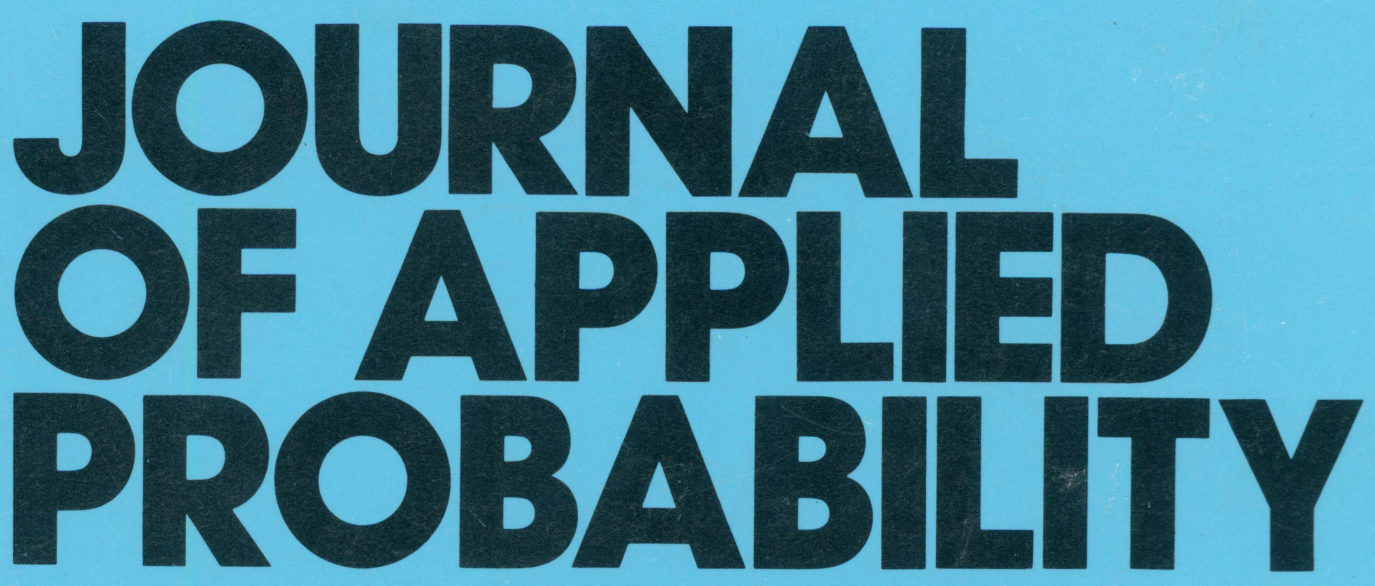

VOLUME 22 NUMBER 1 MARCH 1985

AT EDItor-IN-CHIEF J.GANI 


\section{JOURNAL OF APPLIED PROBABILITY}

This is an international journal published by the Applied Probability Trust in association with the London Mathematical Society; it contains research papers and notes on applications of probability theory to the biological, physical, social and technological sciences. An annual volume of approximately 800 pages is published in four issues appearing in March, June, September and December.

\section{EDITORIAL COMMITTEE}

$\begin{array}{ll}\text { Editor-in-Chief } & \text { J. GANI (University of } \text { Kentucky) } \\ \text { Coordinating Editors } & \text { C. C. HEYDE (University of Melbourne) } \\ & \text { M. F. NEUTS (University of Delaware) } \\ & \text { G. E. H. REUTER (Imperial College, London) }\end{array}$

Executive Editor

MAVIS HITCHCOCK (University of Sheffield)

\section{EDITORS}
A. D. BARBOUR (University of Zurich)
V. BARNETT (University of Sheffield)
D. R. COX (Imperial College, London)
P. D. FINCH (Monash University)
E. J. HANNAN (Australian National University)
S. KARLIN (Stanford University)
D. G. KENDALL (University of Cambridge)
M. KIMURA (National Institute of Genetics,
Shizuoka-ken)
YU. V. PROKHOROV (Academy of Sciences of the USSR, Moscow)
W. VERVAAT (Catholic University, Nijmegen)
G. S. WATSON (Princeton University)
P. WHITTLE (University of Cambridge)

TECHNICAL EDITOR KATHLEEN M. LYLE (University of Sheffield)

\section{ADDRESS FOR CORRESPONDENCE}

All correspondence relating to the submission of papers should be sent to:

The Executive Editor,

Applied Probability,

Department of Probability and Statistics,

The University,

Sheffield S3 7RH, England.

Subscription rates and notes for contributors are to be found on the inside back cover. 


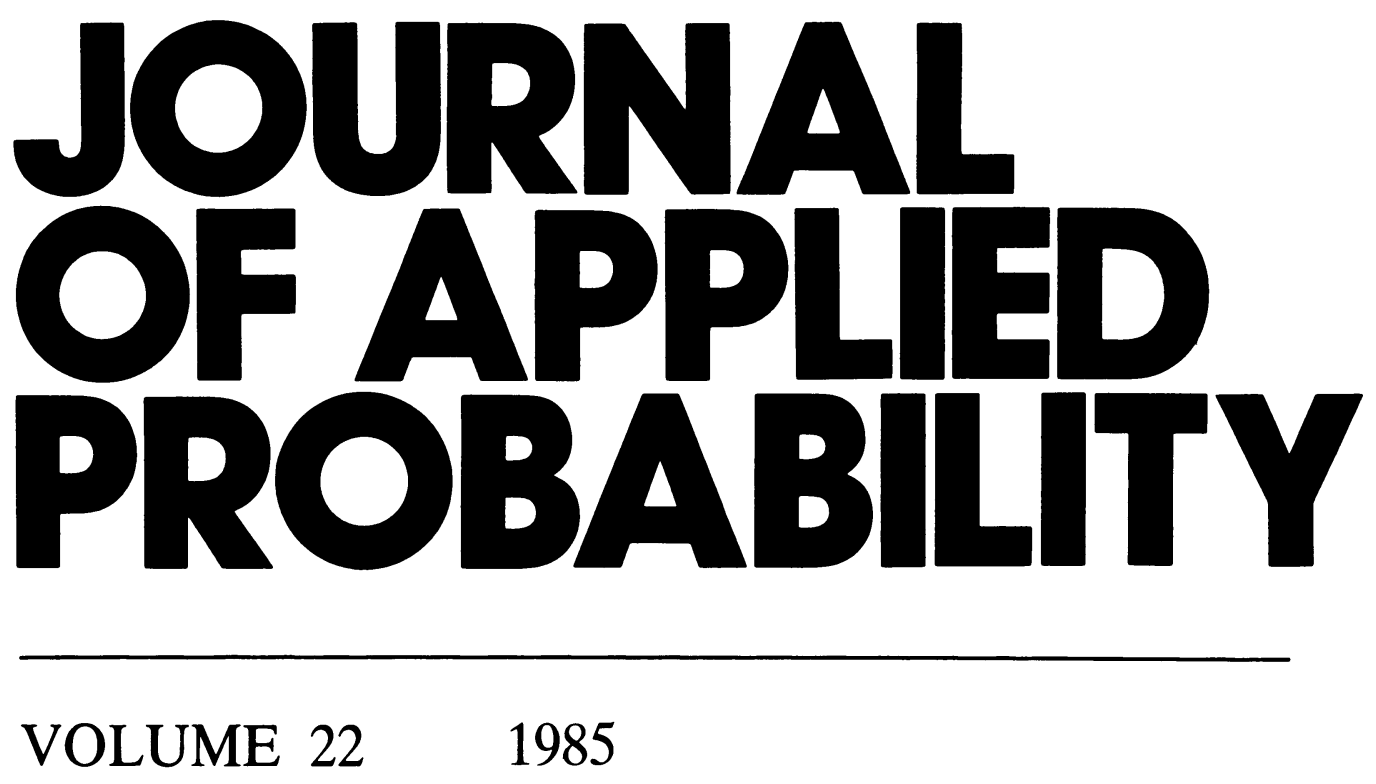

AT EDITOR-IN-CHIEF J.GANI 
Published by the

Applied Probability Trust

in association with the

London Mathematical Society

(C) 1985

ISSN 0021-9002

Authorisation to photocopy items for internal or personal use, or the internal or personal use of specific clients, is granted by the Applied Probability Trust for libraries and other users registered with the Copyright Clearance Center (CCC) Transactional Reporting Service, provided that the base fee of $\$ 00.50$ per copy, plus .10 per page is paid directly to $\mathrm{CCC}, 21$ Congress St., Salem, MA 01970, U.S.A. 0021-9002/85 $\$ 00.50+.10$. 